\title{
Comparative pollen morphology studies on some species of Brassicaceae in Turkey
}

\author{
Ayşe ERDEN *1, Yusuf MENEMEN ${ }^{2}$ \\ ORCID: 0000-0002-8990-0616; 0000-0002-9546-7986
}

\author{
${ }^{1}$ Organized Industry Vocational and Technical Anatolian High School, Ministry of National Education, Yahşihan, \\ Kirikkale, Turkey \\ ${ }^{2}$ Department of Biology, Faculty of Science and Literature, Kırıkkale University, Yahşihan, Kırıkkale, Turkey
}

\begin{abstract}
Pollen aperture type, shape, size, polar axis length, equatorial axis length, P/E ratio, colpus length, thickness of the sexine and nexine, $\mathrm{S} / \mathrm{N}$ ratio, ornamentation type, and lumen shape and width were determined by using light and scanning electron microscope. A multivariate analysis was carried out using the Gover's general similarity coefficient and UPGMA based on 3 qualitative and 8 quantitative pollen characters for 43 taxa belonging to 30 genera and 19 tribes. In all of the taxa studied, the pollen grains were generally small or medium-sized, tricolpate, except in Matthiola longipetala, with an inconspicuous aperture. The shape varied from prolate-spheroidal to perprolate. The exine ornamentation was microreticulate, reticulate, or macroreticulate. In some species, reticulate ornamentation was found together with microreticulate, and in some others, with macroreticulate ornamentation. It was seen that some taxa belonging to some genera placed near each other in the dendogram partially supported some tribes, such as Brassiceae, Alysseae, Sisymbrieae, and Camelineae. It is notable that some closely-related tribes were placed near each other on the dendrogram, which partially supports some previous molecular studies. In addition to exine ornamentation, the pollen size, shape, sexine and nexine thickness, and colpus length were the most useful characters. These characteristics can be used to identify and distinguish some genera, species and partly tribes within the family. They also provide detailed information on the pollen grains of some Brassicaceae taxa, some of which were studied herein for the first time, and this knowledge will be useful for comparisons in future pollen studies.
\end{abstract}

Keywords: Cruciferae, palynology, tribe

\section{Türkiye’deki bazı Brassicaceae türleri üzerine karşılaştırmalı polen morfolojisi çalışmaları}

\section{Özet}

Polen apertür tipi, şekli, boyutu, polar eksen uzunluğu, ekvatoral eksen uzunluğu, P/E oranı, kolpus uzunluğu, sekzin ve nekzin kalınlığı, S/N oranı, süslenme tipi, lümen şekli ve genişliği 1şık ve taramalı electron mikroskobu kullanılarak belirlenmiştir. 19 oymağa ait 30 cinsten 43 takson için 3 nitel ve 8 nicel polen karakterine dayalı olarak Gover's genel benzerlik katsayısı ve UPGMA kullanılarak çok değişkenli bir analiz gerçekleştirilmiştir. İncelenen tüm taksonlarda, polen taneleri genellikle küçük veya orta büyüklükte ve trikolpat olup, Matthiola longipetala'nın dışında belirgin bir apertüre sahiptir. Polen şekli prolat-sferoidalden perprolata kadar değişiklik göstermiştir. Ekzin süslenmesi mikroretikülat, retikülat veya makroretikülattır. Bazı türlerde retikülat süslenme mikroretikülat ile, bazı türlerde de makroretikülat süslenme ile birlikte bulunmuştur. Bazı cinslere ait taksonların dendogram üzerinde birbirine yakın olarak konumlanışı, Brassiceae, Alysseae, Sisymbrieae ve Camelineae gibi bazı oymakların kısmen desteklendiğini göstermektedir. Dendrogramda birbirine yakın konumlanan yakın akraba olan bazı oymakların bazı önceki moleküler çalışmalarda kısmen desteklenmesi dikkate değerdir. Ekzin süslenmesine ek olarak, polen boyutu, şekli, sekzin ve nekzin kalınlığı ve kolpus uzunluğu en kullanışlı karakterlerdir. Bu karakterler familya içindeki bazı cinsleri, türleri kısmen de oymakları tanımlamak ve ayırt etmek için kullanılabilir. Bu karakterler ayrıca, bazıları burada ilk kez

\footnotetext{
* Corresponding author / Haberleşmeden sorumlu yazar: Tel.: +905055275679; Fax.: +9318-3572461; E-mail: ayse.pektas79@ hotmail.com

(C) Copyright 2021 by Biological Diversity and Conservation $\quad$ Received: 18.02.2020; Published: 15.04.2021 
incelenen bazı Brassicaceae taksonlarının polen taneleri hakkında ayrıntılı bilgi sağlamakta olup, elde edilen bu bilgiler gelecekteki polen çalışmalarında karşılaştırmalar için yararlı olacaktır.

Anahtar kelimeler: Cruciferae, oymak, palinoloji

\section{Introduction}

In recent years, molecular biology and DNA techniques have revolutionized the field of plant systematics and phylogenetics. Intensive studies have been carried out and significant changes have been observed in the phylogeny and classification of the family Cruciferae [1,2, 3, 4]. The morphology of pollen grains is a significant tool in solving some taxonomic problems at the family, generic, or specific level, and has become part of the multidisciplinary and collaborative approach in plant systematics and evolution [5]. The number and position of the pores and furrows, complexity of the apertures, form of the sexine, and variation in the size and shape have taxonomic value [6]. The pollen morphology characteristics of the family Brassicaceae has provided an approach to the systematic relationships among the genera and species [7]. Khalik et al. [8] investigated the palynological taxonomy of the tribes in Brassicaceae and concluded that there was a close relationship between Hesperideae, Sisymbrieae, and Arabideae in terms of pollen shape and also indicated that the shape of the pollen grains varied more or less in the genera, depending on the tribe, but rarely varied in species of same genus.

The pollen morphology of the family Brassicaceae has been examined in various research in the literature [9, $10,11,12,13]$. Brassicaceae is a family of stenopalynous pollen grains with tricolpate and usually reticulate ornamentation [14]. The most common pollen shape in the family is prolate, and this type is present in all genera of Brassicaceae [8, 15]. Perveen et al. [16] described the pollen of the family Brassicaceae in Pakistan as radially symmetrical, isopolar, subprolate, prolate, or prolate-spheroidal, rarely oblate-spheroidal, tricolpate, rarely 4-8 colpate. Sagun and Auer [17] stated that pollen grains belonging to 7 genera of the tribe Camelineae (Arabidopsis, Camelina, Capsella, Catolobus, Chrysochamela, Neslia, Noccidium, and Pseudoarabidopsis) were isopolar, and prolate-spheroidal to prolate in shape, and had reticulate and microreticulate ornamentation. Anchev and Deneva [18] examined the pollen grains of 17 species of Brassicaceae and identified 2 types of exine ornamentation (reticulate and perforate), whereas Khalik et al. [8], in his study, grouped the exine ornamentation as microreticulate, reticulate, and macroreticulate according to luminal diameter measurements. Doğan and İnceoğlu [19], Brochmann [20], Khan [15], Pınar et al. [21], Mutlu and Erik [13] stated that pollen morphology may be useful in understanding the relationships among some genera of Brassicaceae. Mutlu and Erik [13] reported the existence of more than one pollen type in some sections of the genus Arabis, and pointed out the parallel evolution and disappearance of some other types. Doğan and İnceoğlu [19] reached the following conclusions from their pollen morphology study of 33 taxa of the genus Isatis L. in Turkey. Pollen grains of the examined taxa showed uniformity in terms of palynological characters. They were radially symmetrical, isopolar, tricolpate; oblate-spheroidal, prolate-spheroidal, or subprolate; circular in polar view; with reticulate ornamentation, and thick sexine. Some Isatis taxa were also found to have syncolpate, tetracolpate, and stephanocolpate pollen grains. Khalik et al. [8] studied the pollen morphology of some tribes in Egypt. The pollen grains of Strigosella africana were determined as prolate in shape and reticulate in exine ornamentation. Kizılpınar et al. [22] examined 5 species of the genus Malcolmia in Turkey. It was reported that the pollen of these taxa had tricolpate and reticulate ornamentation; the pollen shape was prolate-spheroidal or oblate-spheroidal. Karaismailoğlu [23] studied the pollen morphology of 11 taxa belonging to the genus Aethionema W.T. Aiton in Turkey, and described Aethionema pollen grains as mostly isopolar, bilaterally symmetrical, tricolpate, spheroidal, prolate, perprolate, and subprolate in shape, and micro- or macroreticulate in surface ornamentation. Atçeken et al. [30] reported that four Aethionema species in their study had reticulate pollen ornamentation but their muri were different each other in point of their palynological features.

The aim of the present study was to examine and verify the pollen morphological characteristics of certain tribes, and study the diversity and range of variation present among species, and use these data in the taxonomy of the Brassicaceae in Turkey.

\section{Materials and methods}

Pollen grains were obtained from dried herbarium specimens. The unopened buds of the specimens were squashed and the floral parts were removed and placed into a watch glass and examined using a few drops of water and dissection needle under a stereo-microscope. A list of voucher specimens of the studied taxa and their current classification according to Kiefer et al. [33]. are given in Table 1. Some pollen grains were transferred to the stubs, which had been previously prepared with double-sided adhesive tape for the SEM study. The stubs were then coated with gold for 5-6 min. Photographs of the pollen grains were taken using a JSM-6060 JEOL SEM (Tokyo, Japan) (Figure 2-4). The remaining pollen grains were acetolyzed according to the method of Erdtman [24, 25] and transferred onto slides using glycerine jelly, with the addition of safranine stain, to prepare the light microscope slides. After the glycerine jelly melted on the heating block, cover slips were added [26]. A Nikon light microscope (Tokyo, Japan) was used to take the measurements and photographs of the pollen grains (Figure 5-6). 
The pollen aperture type, shape, size, polar axis length, equatorial axis length, $\mathrm{P} / \mathrm{E}$ ratio, colpus length, thickness of the sexine and nexine, $\mathrm{S} / \mathrm{N}$ ratio, ornamentation type, and lumen (lumina) shape and width were determined by measuring the maximum number of pollen grains (10-30) for each species and the mean values are given in brackets in Table 2. The palynological terminology followed was according to that of Erdtman [14] for the pollen size classification and that of Punt et al. [27] was followed for the other terminology.

A data matrix was prepared for the analysis, which included 3 qualitative and 8 quantitative pollen characteristics (pollen shape and size, polar axis length, equatorial axis length, P/E ratio, colpus length, sexine width, nexine width, $\mathrm{S} / \mathrm{N}$ ratio, lumen width, and ornamentation type) for the examined taxa. The data were first converted into a similarity matrix using Gower's general similarity coefficient. The similarity matrix was then clustered using UPGMA clustering (Figure 1). The analyses were completed using the multivariate statistics package (MVSP).

Table 1. A list of voucher specimens of the studied taxa and their current classification

\begin{tabular}{|c|c|c|}
\hline Tribes & Species/Subspecies & Specimen collectors \& number \\
\hline Aethionemeae & Aethionema armenum & A.Erden 1072 ve Y.Menemen \\
\hline Aethionemeae & Aethionema dumanii & A.Erden 1440 ve Y.Menemen \\
\hline Alysseae & Alyssum turkestanicum & A.Erden 1103 ve Y.Menemen \\
\hline Alysseae & Odontarrhena sibirica & A.Erden 1117,1056 ve Y.Menemen \\
\hline Alysseae & Meniocus linifolius & A.Erden 1043 ve Y.Menemen \\
\hline Alysseae & Odontarrhena muralis & A.Erden 1153 ve Y.Menemen \\
\hline Alysseae & Alyssum simplex & A.Erden 1383 ve Y.Menemen \\
\hline Alysseae & Fibigia clypeata & Eftal 1754 \\
\hline Anchonieae & Matthiola longipetala subsp. bicornis & A.Erden 1070 ve Y.Menemen \\
\hline Arabideae & Aubrieta libanotica & A.Erden 1361 ve Y.Menemen \\
\hline Arabideae & Draba nana & A.Erden 1365 ve Y.Menemen \\
\hline Brassiceae & Brassica nigra & A.Erden 1330 ve Y.Menemen \\
\hline Brassiceae & Brassica elongata & A.Erden $1129,1051,1390$ ve Y.Menemen \\
\hline Brassiceae & Crambe tataria & A.Erden 1022,1037 ve Y.Menemen \\
\hline Brassiceae & Diplotaxis tenuifolia & A.Erden 1075 ve Y.Menemen \\
\hline Brassiceae & Eruca vesicaria & A.Erden 1231 ve Y.Menemen \\
\hline Brassiceae & Hirschfeldia incana & A.Erden $1142,1108,1027$ ve Y.Menemen \\
\hline Brassiceae & Sinapis arvensis & A.Erden 1150 ve Y.Menemen \\
\hline Calepineae & Calepina irregularis & A.Erden 1095 ve Y.Menemen \\
\hline Camelineae & Capsella bursa-pastoris & A.Erden 1238 ve Y.Menemen \\
\hline Camelineae & Camelina hispida & A.Erden 1047,1110 ve Y.Menemen \\
\hline Camelineae & Camelina rumelica & A.Erden 1119 ve Y.Menemen \\
\hline Camelineae & Neslia apiculata & A.Erden 1242 ve Y.Menemen \\
\hline Cardamineae & Barbarea vulgaris & A.Erden 1337,1340 ve Y.Menemen \\
\hline Chorisporeae & Chorispora tenella & A.Erden 1283 ve Y.Menemen \\
\hline Coluteocarpeae & Microthlaspi perfoliatum & A.Erden 1266 ve Y.Menemen \\
\hline Conringieae & Conringia orientalis & A.Erden 1501 ve Y.Menemen \\
\hline Descurainieae & Descurainia sophia & A.Erden 1169 ve Y.Menemen \\
\hline Erysimeae & Erysimum cuspidatum & A.Erden 1220 ve Y.Menemen \\
\hline Erysimeae & Erysimum repandum & A.Erden 1300 ve Y.Menemen \\
\hline Erysimeae & Erysimum smyrnaeum & A.Erden 1135 ve Y.Menemen \\
\hline Erysimeae & Erysimum crassipes & A.Erden 1054 ve Y.Menemen \\
\hline Euclidieae & Strigosella africana & A.Erden 1116,1065 ve Y.Menemen \\
\hline Hesperideae & Hesperis bicuspidata & A.Erden 1364 ve Y.Menemen \\
\hline Isatideae & Isatis quadrialata & A.Erden 1052 ve Y.Menemen \\
\hline Isatideae & Isatis glauca & A.Erden 1196 ve Y.Menemen \\
\hline Lepidieae & Lepidium draba & A.Erden 1001,1049 ve Y.Menemen \\
\hline Lepidieae & Lepidium perfoliatum & A.Erden 1094,1239 ve Y.Menemen \\
\hline Sisymbrieae & Sisymbrium altissimum & A.Erden 1151,1200 ve Y.Menemen \\
\hline Sisymbrieae & Sisymbrium orientale & A.Erden 1120,1514 ve Y.Menemen \\
\hline Sisymbrieae & Sisymbrium irio & A.Erden 1452 ve Y.Menemen \\
\hline Sisymbrieae & Sisymbrium loeselii & A.Erden 1241,1003 ve Y.Menemen \\
\hline Thlaspideae & Thlaspi arvense & A.Erden 1354 ve Y.Menemen \\
\hline
\end{tabular}




\section{Results}

In this study, pollen morphology of 43 species, representing 30 genera of 19 tribes, belonging to the family Brassicaceae were investigated. The pollen aperture type, shape, size, polar axis length, equatorial axis length, P/E ratio, colpus length, thickness of sexine and nexine, $\mathrm{S} / \mathrm{N}$ ratio, ornamentation type, lumen shape, and width were determined for each taxa (Table 2, Figure 2-6).

\subsection{Aperture type}

In the taxa studied, the pollen grains were tricolpate, and only Matthiola longipetala had an inconspicuous aperture. The colpus was generally the widest in the equatorial axis and became narrower towards the poles.

\subsection{Pollen size}

In the examined species, the polar axis length was between 10.9 and $35.97 \mu \mathrm{m}$ and the equatorial axis length ranged from 5.45 to $29.43 \mu \mathrm{m}$. The smallest pollen grains among the studied species belonged to Descurainia sophia, in which the mean polar axis length was $13.32 \mu \mathrm{m}$ and the equatorial axis length was $8.47 \mu \mathrm{m}$. The pollen grains of Fibigia clypeata had a mean polar axis length of $33.68 \mu \mathrm{m}$ and an equatorial axis length of $22.45 \mu \mathrm{m}$, and were determined as the largest. It can easily be said that the pollen grains of the family were small-or medium-sized in general.

\subsection{Pollen shape}

According to Erdtman [28], the ratio of the polar axis length to the equatorial axis length determines the shape of the pollen grains. Hence, a polar/equatorial axis (P/E) ratio between 0.88 and 1.14 is spheroidal, 1 and 1.14 is prolate spheroidal, 1.14 and 1.33 is subprolate, 1.33 and 2 is prolate, and $>2$ is perprolate. The P/E ratio of the pollen of the studied species was between $1.06 \mu \mathrm{m}$ and $2.08 \mu \mathrm{m}$, and the pollen shape differed from prolate-spheroidal to perprolate.

\subsection{Colpus length}

In the pollen grains of the examined species, the colpus length was between 9.5 and $32.7 \mu \mathrm{m}$. The shortest colpus was found in Descurainia sophia, while the longest was in Fibigia clypeata.

3.5. Thickness of sexine and nexine, $S / \mathrm{N}$ ratio

Among the species, the sexine thickness was between $0.5 \mu \mathrm{m}$, as in Odontarrhena sibirica, and $2.55 \mu \mathrm{m}$, as in Matthiola longipetala. The nexine thickness was between $0.15 \mu \mathrm{m}$, as in Barbarea vulgaris, and $0.82-1 \mu \mathrm{m}$, as in Brassica nigra. The $\mathrm{S} / \mathrm{N}$ ratio was the lowest in Aethionema dumanii $(1.06-1.11 \mu \mathrm{m})$ and highest in Lepidium perfoliatum $(5-5.33 \mu \mathrm{m})$.

\subsection{Ornamentation type, lumen (lumina) shape and width}

In the pollen grains of Brassicaceae, the basic ornamentation type was reticulate. The reticulum was heterobrochate. The murus surface was smooth, slightly wavy, or sinuous. The lumen shape differed from circular to elliptical, elongated, or irregular. The width of the lumen diameter was generally large around the equatorial region, and smaller through the poles. According to the sizes of luminal diameter, 3 different types of exine ornamentation were determined [8]. If the lumen diameter is less than $1 \mu \mathrm{m}$, the ornamentation is microreticulate, between 1 and $2 \mu \mathrm{m}$ is reticulate, and $>2 \mu \mathrm{m}$, is macroreticulate.

Microreticulate exine ornamentation was seen in species of Aethionema armenum, Aethionema dumanii, Meniocus linifolius, Odontarrhena muralis, Draba nana, Camelina rumelica, Neslia apiculata, Barbarea vulgaris, Descurainia sophia, Erysimum cuspidatum, Erysimum smyrnaeum, Lepidium draba, Lepidium perfoliatum, and Thlaspi arvense, while macroreticulate ornamentation was only seen in Sinapis arvensis. In some of the other species, reticulate ornamentation was found together with microreticulate and in some species, it was with macroreticulate ornamentation.

\subsection{UPGMA analysis}

The dendrogram obtained from the similarity matrix using the Gower's general similarity coefficient and UPGMA clustering method is presented in Figure 1, where it can be seen that some members of the genera placed near each other partially contributed to the formation of some tribal branches, such as Brassiceae, Alysseae, Sisymbrieae, and Camelineae. 
Table 2. Pollen grain characteristics of the examined taxa belonging to the Brassicaceae

\begin{tabular}{|c|c|c|c|c|c|}
\hline Taxa /Characteristics & Shape & Size & Polar axis lenght $(\mu \mathrm{m})$ & Equatorial axis lenght $(\mu \mathrm{m})$ & $\mathrm{P} / \mathrm{E}(\mu \mathrm{m})$ \\
\hline Aethionema armenum & subprolate to perprolate & small & $16.35-(18.62)-21.8$ & $9.81-(11.89)-15.26$ & $1.28-(1.58)-2.11$ \\
\hline Aethionema dumanii & subprolate to prolate & small & $16.35-(19.51)-25.07$ & $10.9-(12.86)-14.17$ & $1.23-(1.52)-1.91$ \\
\hline Alyssum turkestanicum & subprolate to prolate & medium & $26.16-(31.28)-34.88$ & $20.71-(22.34)-25.07$ & $1.20-(1.40)-1.63$ \\
\hline Meniocus linifolius & prolate-spheroidal to prolate & small & 17.44-(19.52)-23.98 & $11.99-(14.36)-18.53$ & $1.14-(1.37)-1.63$ \\
\hline Odontarrhena muralis & subprolate to prolate & small and medium & $21.8-(25.07)-29.43$ & $14.17-(16.25)-19.62$ & $1.31-(1.54)-1.85$ \\
\hline Odontarrhena sibirica & prolate to perprolate & small and medium & $19.62-(24.87)-28.34$ & $12.53-(14.91)-18.53$ & $1.42-(1.67)-2.08$ \\
\hline Alyssum simplex & subprolate to prolate & medium & $26.16-(29.97)-35.97$ & $18.53-(20.49)-25.07$ & $1.25-(1.46)-1.83$ \\
\hline Fibigia clypeata & subprolate to prolate & medium & $29.43-(33.68)-35.97$ & $19.62-(22.45)-27.25$ & $1.28-(1.52)-1.83$ \\
\hline Matthiola longipetala & prolate-spheroidal to subprolate & small and medium & $22.89-(26.05)-29.43$ & 17.44-(21.36)-23.98 & $1.09-(1.22)-1.33$ \\
\hline Aubrieta libanotica & subprolate to prolate & small and medium & $19.62-(25.83)-30.52$ & $14.17-(17.66)-21.8$ & $1.23-(1.47)-1.76$ \\
\hline Draba nana & prolate -spheroidal to prolate & small and medium & 19.62-(21.90)-26.16 & $11.99-(15.26)-19.62$ & $1.11-(1.45)-1.81$ \\
\hline Brassica nigra & subprolate to prolate & small and medium & $22.89-(26.16)-30.52$ & $15.26-(18.96)-22.89$ & $1.28-(1.38)-1.50$ \\
\hline Brassica elongata & subprolate to prolate & medium & $25.07-(27.15)-33.79$ & $16.35-(18.62)-27.25$ & $1.24-(1.47)-1.62$ \\
\hline Crambe tataria & subprolate to prolate & small and medium & $23.98-(29.53)-31.61$ & $19.62-(21.80)-23.98$ & $1.15-(1.36)-1.55$ \\
\hline Diplotaxis tenuifolia & subprolate to prolate & medium & $25.07-(30.73)-35.97$ & $16.35-(22.67)-29.43$ & $1.18-(1.37)-1.52$ \\
\hline Eruca vesicaria & prolate & small & $15.26-(17.49)-20.16$ & $10.9-(12.64)-15.26$ & $1.32-(1.39)-1.60$ \\
\hline Hirschfeldia incana & subprolate to prolate & small and medium & $20.71-(26.92)-31.61$ & $15.26-(18.53)-22.89$ & $1.31-(1.45)-1.66$ \\
\hline Sinapis arvensis & subprolate to prolate & small and medium & 21.8-(28.83)-34.88 & 17.44-(20.11)-23.98 & $1.25-(1.43)-1.60$ \\
\hline Calepina inregularis & subprolate to prolate & small and medium & $21.8-(24.52)-27.25$ & $15.26-(18.09)-20.71$ & $1.21-(1.36)-1.52$ \\
\hline Capsella bursa-pastoris & subprolate to prolate & small & $17.44-(20.27)-22.89$ & 11.99-(14.22)-17.44 & $1.30-(1.43)-1.66$ \\
\hline Camelina hispida & subprolate to prolate & small & $19.62-(22.69)-25.07$ & $13.08-(15.55)-17.44$ & $1.25-(1.46)-1.75$ \\
\hline Camelina rumelica & subprolate to prolate & small and medium & $21.8-(25.96)-29.43$ & $16.35-(18.33)-21.8$ & $1.25-(1.42)-1.66$ \\
\hline Neslia apiculata & subprolate to prolate & small and medium & $20.71-(23.88)-30.52$ & $14.17-(17.04)-19.62$ & $1.18-(1.40)-1.55$ \\
\hline Barbarea vulgaris & subprolate to prolate & small & $17.44-(19.94)-21.8$ & $10.9-(14.17)-16.35$ & $1.21-(1.42)-1.80$ \\
\hline Chorispora tenella & subprolate to perprolate & small & 17.44-(19.83)-23.98 & $9.81-(13.02)-15.26$ & $1.21-(1.55)-2.11$ \\
\hline Microthlaspi perfoliatum & subprolate to prolate & small and medium & $20.71-(24.37)-28.34$ & $16.35-(17.34)-18.53$ & $1.25-(1.40)-1.66$ \\
\hline Conringia orientalis & subprolate to prolate & small & $17.44-(19.40)-22.89$ & $14.27-(14.66)-15.26$ & $1.21-(1.33)-1.61$ \\
\hline Descurainia sophia & Prolate & small & $10.9-(13.32)-15.26$ & $5.45-(8.47)-10.9$ & $1.33-(1.60)-2.00$ \\
\hline Erysimum cuspidatum & subprolate to prolate & small and medium & $16.35-(26.16)-30.52$ & $13.08-(17.33)-20.71$ & $1.25-(1.50)-1.73$ \\
\hline Erysimum repandum & subprolate to prolate & small and medium & 17.44-(24.41)-30.52 & $14.17-(17.65)-19.62$ & $1.22-(1.38)-1.55$ \\
\hline Erysimum smyrnaeum & subprolate to prolate & small & $16.35-(22.19)-23.98$ & $10.9-(14.66)-18.53$ & $1.23-(1.53)-1.90$ \\
\hline Erysimum crassipes & prolate -spheroidal to prolate & small & $14.17-(16.05)-19.62$ & $9.81-(11.39)-13.08$ & $1.08-(1.41)-1.55$ \\
\hline Strigosella africana & subprolate to prolate & small & $16.35-(19.22)-21.8$ & $10.9-(13.67)-16.35$ & $1.21-(1.41)-1.66$ \\
\hline Hesperis bicuspidata & prolate-spheroidal to prolate & small & $17.44-(21.40)-25.07$ & $11.99-(15.26)-19.62$ & $1.11-(1.42)-1.76$ \\
\hline Isatis quadrialata & subprolate to prolate & small and medium & $22.89-(25.72)-29.43$ & $15.26-(18.09)-20.71$ & $1.27-(1.42)-1.53$ \\
\hline Isatis glauca & subprolate to prolate & small and medium & $22.89-(26.92)-30.52$ & $16.35-(21.36)-23.98$ & $1.11-(1.26)-1.46$ \\
\hline Lepidium draba & subprolate to prolate & medium & $29.43-(32.26)-35.97$ & $19.62-(21.80)-23.98$ & $1.31-(1.49)-1.83$ \\
\hline Lepidium perfoliatum & subprolate to prolate & small and medium & $18.53-(22.69)-27.25$ & $14.17-(16.94)-20.71$ & $1.13-(1.34)-1.53$ \\
\hline Sisymbrium altissimum & prolate-spheroidal to prolate & small & $16.35-(19.29)-22.89$ & $11.99-(14.61)-16.35$ & $1.06-(1.32)-1.45$ \\
\hline Sisymbrium orientale & subprolate to prolate & small & $15.26-(20.38)-25.07$ & $10.9-(14.61)-17.44$ & $1.26-(1.39)-1.64$ \\
\hline Sisymbrium irio & subprolate to prolate & small & $16.35-(21.01)-23.98$ & $9.81-(13.67)-15.26$ & $1.28-(1.54)-1.69$ \\
\hline Sisymbrium loeselii & subprolate to prolate & small & $16.35-(17.53)-18.53$ & 9.81-(12.18)-15.26 & $1.21-(1.45)-1.77$ \\
\hline Thlaspi arvense & subprolate to prolate & small and medium & $17.44-(22.09)-29.43$ & $14.17-(15.75)-19.62$ & $1.23-(1.39)-1.57$ \\
\hline
\end{tabular}


Table 2. Contunied

\begin{tabular}{|c|c|c|c|c|c|c|}
\hline Taxa/Characteristics & $\begin{array}{l}\text { Colpus lenght } \\
(\mu \mathrm{m})\end{array}$ & \begin{tabular}{|l|}
$\begin{array}{l}\text { Sexine thickness } \\
(\mu \mathrm{m})\end{array}$ \\
\end{tabular} & \begin{tabular}{|l|}
$\begin{array}{l}\text { Nexine thickness } \\
(\mu \mathrm{m})\end{array}$ \\
\end{tabular} & $\mathrm{S} / \mathrm{N}$ ratio & $\begin{array}{l}\begin{array}{l}\text { Widht of lumen } \\
(\mu \mathrm{m})\end{array} \\
\end{array}$ & Type of Ornamentation \\
\hline Aethionema armenum & $13.08-15.26$ & $0.63-0.72$ & $0.2-0.25$ & $2.88-3.15$ & $0.615-1.05$ & microreticulate \\
\hline Aethionema dumanii & $11.99-14.17$ & $0.85-1$ & $0.8-0.9$ & $1.06-1.11$ & $0.714-0.992$ & microreticulate \\
\hline Alyssum turkestanicum & $23.98-32.7$ & $0.85-1.10$ & $0.25-0.30$ & $3.4-3.66$ & $0.656-1.31$ & microreticulate and reticulate \\
\hline Meniocus linifolius & $16.35-23.98$ & $0.81-0.87$ & $0.44-0.54$ & $1.5-1.97$ & $0.680-0.837$ & microreticulate \\
\hline Odontarrhena muralis & $21.8-26.16$ & $0.8-1$ & $0.21-0.45$ & $2.22-3.8$ & $0.520-0.755$ & microreticulate \\
\hline Odontarrhena sibirica & $16.35-19.62$ & $0.5-0.55$ & $0.25-0.35$ & $1.57-2$ & $0.707-1.14$ & microreticulate and reticulate \\
\hline Alyssum simplex & $27.25-29.43$ & $0.75-0.82$ & $0.15-0.20$ & $4.1-5$ & $0.667-1.77$ & microreticulate and reticulate \\
\hline Fibigia clypeata & $27.25-32.7$ & $0.85-1$ & $0.25-0.35$ & $2.85-3.4$ & $0.767-1.11$ & microreticulate and reticulate \\
\hline Matthiolalongipetala & $19.62-23.98$ & $2.2-2.55$ & $0.4-0.6$ & $4.25-5.5$ & $1.68-3.78$ & reticulate to macroreticulate \\
\hline Aubrieta libanotica & $16.35-27.25$ & $1.9-2$ & $0.5-0.6$ & $3.33-3.8$ & $0.683-2.19$ & microreticulate and reticulate \\
\hline Draba nana & $14.17-19.60$ & $1.25-1.3$ & $0.52-0.6$ & $2.16-2.40$ & $0.692-1.01$ & microreticulate \\
\hline Brassica nigra & 21.827 .25 & $1.20-1.25$ & $0.82-1$ & $1.2-1.52$ & $1.11-3.76$ & reticulate to macroreticulate \\
\hline Brassica elongata & $18.52-30.52$ & $1.20-1.35$ & $0.7-0.8$ & $1.68-1.71$ & $0.644-1.58$ & microreticulate and reticulate \\
\hline Crambe tataria & $19.52-25.07$ & $1.75-2$ & $0.45-0.5$ & $3.88-4$ & $0750-1.92$ & microreticulate and reticulate \\
\hline Diplotaxis tenuifolia & $22.50-32.25$ & $1.9-2.2$ & $0.5-0.6$ & $3.66-3.88$ & $0.984-2.97$ & reticulate to macroreticulate \\
\hline Eruca vesicaria & $10.9-13.08$ & $0.85-0.9$ & $0.22-0.25$ & $3.6-3.86$ & $0.698-1.38$ & microreticulate and reticulate \\
\hline Hirschfeldia incana & $19.62-27.25$ & $1.6-1.8$ & $0.5-0.7$ & $2.57-3.2$ & $0.802-2.09$ & reticulate to macroreticulate \\
\hline Sinapis arvensis & $21.8-31.50$ & $2-2.1$ & $0.45-0.50$ & $4-4.66$ & $2.16-4.96$ & macroreticulate \\
\hline Calepina irregularis & $17.44-21.8$ & $2.15-2.35$ & $0.75-0.85$ & $2.76-2.86$ & $0.693-1.58$ & microreticulate and reticulate \\
\hline Capsella bursa-pastoris & $15.26-19.62$ & $0.75-0.87$ & $0.25-0.32$ & $2.71-3$ & $0.698-1.22$ & microreticulate and reticulate \\
\hline Camelina hispida & 17.44-22.89 & $0.8-0.85$ & $0.45-0.52$ & $1.63-1.77$ & $0.687-1.41$ & microreticulate and reticulate \\
\hline Camelina rumelica & $18.53-27.25$ & $0.8-1.1$ & $0.5-0.75$ & $1.46-1.6$ & $0.641-1.03$ & microreticulate \\
\hline Neslia apiculata & $15.30-21.8$ & $1-1.25$ & $0.5-0.8$ & \begin{tabular}{|l|}
$1.56-2$ \\
\end{tabular} & $0.641-0.751$ & microreticulate \\
\hline Barbarea vulgaris & $15.20-21.8$ & $0.75-0.8$ & $0.15-0.18$ & $4.44-5$ & $0.680-0.966$ & microreticulate \\
\hline Chorispora tenella & $13.08-18.53$ & $1-1.1$ & $0.4-0.45$ & $2.22-2.75$ & $0.659-1.48$ & microreticulate and reticulate \\
\hline Microthlaspi perfoliatum & $19.62-26.16$ & $1-1.2$ & $0.52-0.6$ & $1.92-2$ & $0.641-1.67$ & microreticulate and reticulate \\
\hline Conringia orientalis & 17.44-22.89 & $1-1.1$ & $0.8-0.9$ & $1.22-1.25$ & $0.686-1.25$ & microreticulate and reticulate \\
\hline Descurainia sophia & $9.5-13.20$ & $0.75-0.8$ & $0.2-0.25$ & $3.2-3.75$ & $0.615-0.717$ & microreticulate \\
\hline Erysimum cuspidatum & $17.44-23.98$ & $1.1-1.3$ & $0.6-0.8$ & $1.62-1.83$ & $0.612-0.845$ & microreticulate \\
\hline Erysimum repandum & $15.26-19.62$ & $1-1.1$ & $0.5-0.6$ & $1.66-2.2$ & $0.717-1.84$ & microreticulate and reticulate \\
\hline Erysimum smyrnaeum & $15.26-22.89$ & $0.8-1.1$ & $0.5-0.65$ & $1.6-1.69$ & \begin{tabular}{|l|}
$0.714-0.975$ \\
\end{tabular} & microreticulate \\
\hline Erysimum crassipes & $11.99-17.45$ & $0.75-0.8$ & $0.28-0.4$ & $2-2.67$ & $0.651-1.58$ & microreticulate and reticulate \\
\hline Strigosellaafiicana & \begin{tabular}{|l|}
$14.17-21.8$ \\
\end{tabular} & $1.25-1.60$ & $0.5-0.55$ & $2.5-2.9$ & $0.743-2$ & microreticulate and reticulate \\
\hline Hesperis bicuspidata & $16.35-19.62$ & $0.8-1$ & $0.15-0.2$ & $5-5.3$ & $0.709-2.16$ & microreticulate and reticulate \\
\hline Isatis quadrialata & $16.35-23.98$ & \begin{tabular}{|l|}
$1-1.2$ \\
\end{tabular} & $0.3-0.45$ & $2.66-3.33$ & $0.703-1.59$ & microreticulate and reticulate \\
\hline Isatis glauca & $16.35-21.8$ & $1.63-2.1$ & $0.75-0.87$ & $1.87-2.8$ & $0.705-1.62$ & microreticulate and reticulate \\
\hline Lepidium draba & $23.98-28.34$ & $1-1.1$ & $0.8-0.9$ & $1.22-1.25$ & $0.685-1.05$ & microreticulate \\
\hline Lepidium perfoliatum & $16.35-23.98$ & $0.8-1$ & $0.15-0.2$ & $5-5.33$ & $0.712-0.989$ & microreticulate \\
\hline Sisymbrium altissimum & $19.62-21.8$ & $1.52-1.6$ & $0.4-0.45$ & $3.37-4$ & $0.717-2.35$ & microreticulate and reticulate \\
\hline Sisymbrium orientale & $13.08-21.8$ & $1-1.1$ & $0.25-0.3$ & $3.66-4$ & $0.687-1.58$ & microreticulate and reticulate \\
\hline Sisymbrium irio & $10.9-20.71$ & $1-1.1$ & $0.3-0.35$ & $3.14-3.33$ & $0.721-1.99$ & microreticulate and reticulate \\
\hline Sisymbrium loeselii & $11.99-14.17$ & $0.75-0.8$ & $0.2-0.25$ & $3.2-3.75$ & $0.644-1.51$ & microreticulate and reticulate \\
\hline Thlaspi arvense & $16.35-19.62$ & $1-1.1$ & $0.8-1$ & $1.1-1.25$ & $0.632-1.07$ & microreticulate \\
\hline
\end{tabular}

\section{Conclusions and discussion}

Pollen shapes within a genus, or even within a tribe, did not show great differences in the studied taxa. The pollen grains examined were radial symmetrical and isopolar, and ranged from prolate-spheroidal to perprolate in shape. The most common pollen shapes determined within the tribes were subprolate and prolate. Prolate-spheroidal and perprolate pollen grains were found in a few taxa. These results were consistent with those of previous studies (prolate and subspheroidal [29]; prolate-spherodial, subprolate, prolate [18]; subprolate, prolate, spheroidal [30] and prolate [8]). Although the pollen grains showed uniformity, with slight differences in shape, in Camelineae, Isatideae, Lepidieae, Brassiceae (subprolate and prolate), they did not in Aethionemeae, Alysseae, Arabideae, Erysimeae, and Sisymbrieae tribes. All the studied taxa had a tricolpate pollen aperture, except for Matthiola longipetala, which had indistinct colpi. Erdtman [9], Jonsell [31], Lahham and Al-Eisawi [29], and İnceoğlu and Karamustafa [32] reported that the colpi were absent or less prominent in a few Matthiola species.

The pollen grains in the taxa were generally small or medium sized. Pollen size sometimes has taxonomical importance at the tribe level and at other times at the genus or species level. Aethionemeae, Sisymbrieae, Cardamineae, 
Chorisporeae, Conringieae, Descurainieae, Euclidieae, and Hesperideae had only small-sized pollen grains, while the others had both small- and medium-sized pollen. The longest pollen grains were seen in Alyssum simplex, Fibigia clypeata, and Lepidium draba, with a polar axis length of $35.97 \mu \mathrm{m}$, while the shortest pollen grains were in Descurainia sophia with a polar axis length of $10.9 \mu \mathrm{m}$.

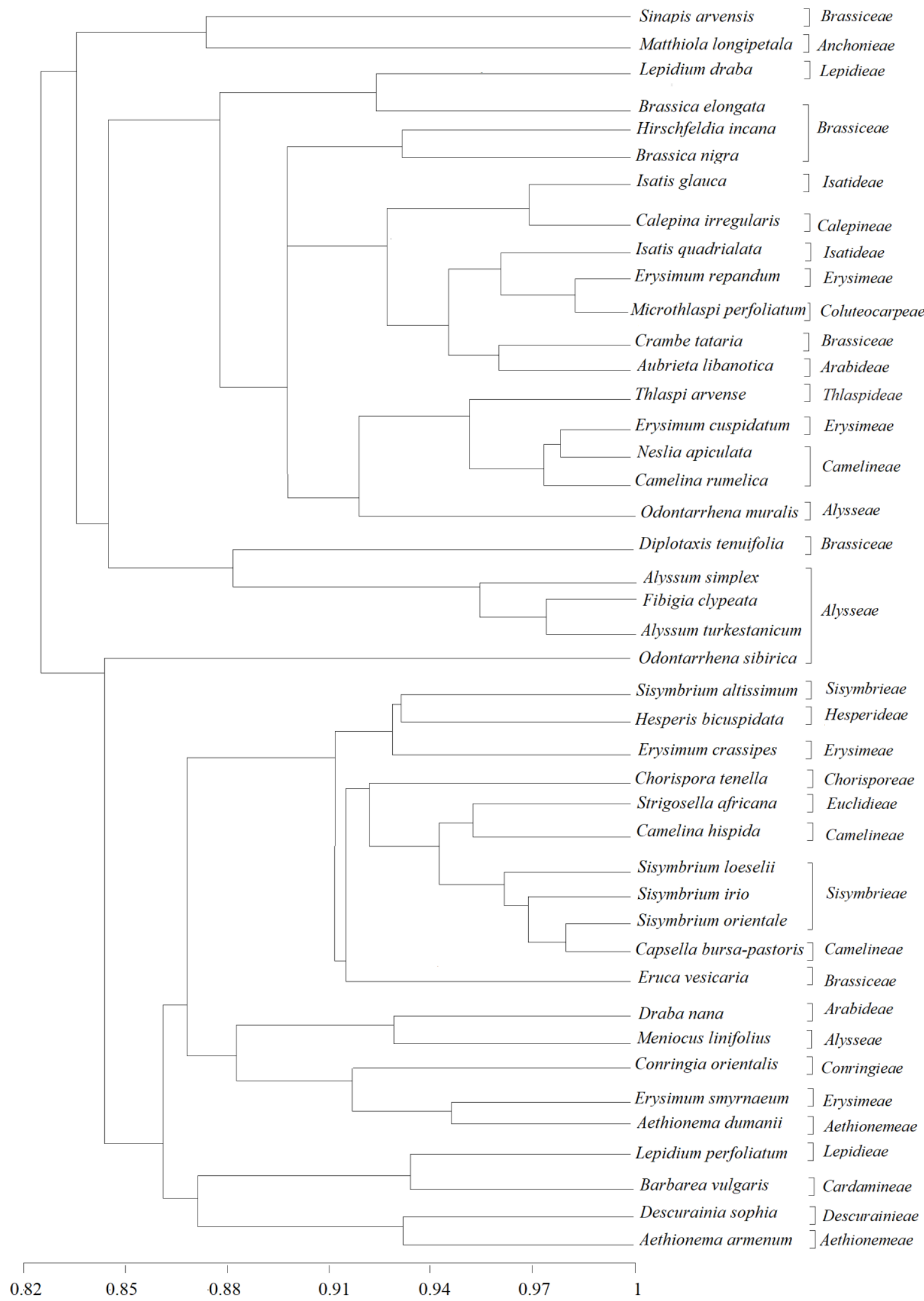

Figure 1. A dendrogram of 43 taxa examined in this study, based on Gower's General Similarity Coefficient using UPGMA clustering method with qualitative and quantitative pollen characters. 
In the family Brassicaceae, the exine ornamentation was microreticulate, reticulate and macroreticulate. Khalik et al. [8] stated that ornamentation has an important role in the family, and it differs between genera within a tribe and species within the same genus. However, the exine ornamentation is inadequate to distinguish tribes and genera studied within the same tribe, while it is sometimes useful in distinguishing some species within the same genus. For example, Brassica nigra differs from B. elongata, by its reticulate and macroreticulate exine ornamentation (Table 2). The pollen grains of all the taxa studied within the same tribe had the same exine ornamentation in some cases, such as Aethionemeae and Lepidieae. Sometimes pollen grains of the same species have both microreticulate and reticulate ornamentation, while some species may have both reticulate and macroreticulate ornamentation on the same pollen grain. This, contrary to what Khalik et al. [8] stated, shows that exine ornamentation is not always uniformity in taxa and does not always suffice to distinguish between taxa at tribe and genus level in the family. While the exine ornamentation was microreticulate in Aethionemeae, Cardamineae, Descurainieae, Lepidieae, and Thlaspideae, it appeared to be mixed in the other tribes. Macroreticulate ornamentation was observed in 5 species belonging to 2 tribes. These were Matthiola longipetala from Anchonieae and Brassica nigra, Diplotaxis tenuifolia, Hirschfeldia incana, and Sinapis arvensis from Brassiceae. The largest lumens were found in Sinapis arvensis, at 2.16-4.96 $\mu \mathrm{m}$. As some of the tribes and genera were examined in this study with single genus or species, respectively, and the difference between these taxa could not be clearly determined.

In this study, it was observed that pollen characteristics can be useful, especially in the differentiation of species in many cases. However, there are some taxa with the same pollen characteristics in different genera and tribes.

In addition, in the UPGMA tree (Figure 1) constructed using the pollen characteristics, it was clearly seen that species belonging to the tribes of Brassiceae, Alysseae, Sisymbrieae, and Camelineae were partially together or located close to each other. For example, Brassica elongata, Hirschfeldia incana, and Brassica nigra belonged to Brassiceae; Alyssum simplex, Fibigia clipeata, Alyssum turkestanicum, and Odontarrhena sibirica belonged to Alysseae; Sisymbrium looselii, Sisymbrium irio, and Sisymbrium orientale belonged to Sisymbrieae, and Neslia apiculata and Camelina rumelica belonged to Camelineae. It was seen that Sisymbrium altissimum and Odontarrhena muralis differed from the other Sisymbrium species and $O$. sibirica, respectively, by the features of the colpus length and sexine thickness. It is also noteworthy that in the molecular analysis [33], some closely related tribes were also placed close to each other on the UPGMA dendrogram, such as the tribes of Camelineae and Erysimeae, and Chorisporeae and Euclidieae

In some previous pollen studies, some of the Brassicaceae taxa that were included in this study were examined. Çitak et al. [34] investigated the pollen morphology of 3 Turkish Brassicaceae taxa that were also examined in the present study. In both studies, the exine ornamentation of the pollen was reticulate. However, some slight differences were found in their pollen shapes. In the study of Çitak et al. [34], the pollen shape was prolate-spheroidal in Odontarrhena muralis, oblate-spheroidal in Diplotaxis tenuifolia, and prolate-spheroidal in Matthiola longipetala subsp. bicornis, whereas it was subprolate and prolate in Odontarrhena muralis and Diplotaxis tenuifolia, and prolatespheroidal and subprolate in Matthiola longipetala subsp. bicornis. Çetin et al. [35] determined that the surface ornamentation of the pollen grains of Fibigia clypeata was reticulate and the aperture type was tricolpate, as was observed in the present study. Khalik et al. [8] reported that the pollen shape of Strigosella africana was prolate and the exine ornamentation was reticulate. In this study, the pollen shape of this taxon was determined as subprolate and prolate and the ornamentation was reticulate with microreticulate.

This study showed that pollen morphological characteristics can be used to identify and distinguish some genera, species and partly tribes within the family. It also provided detailed information on the pollen grains of some Brassicaceae taxa, some of which were studied herein for the first time, and this knowledge will be useful for comparisons in future pollen studies. 

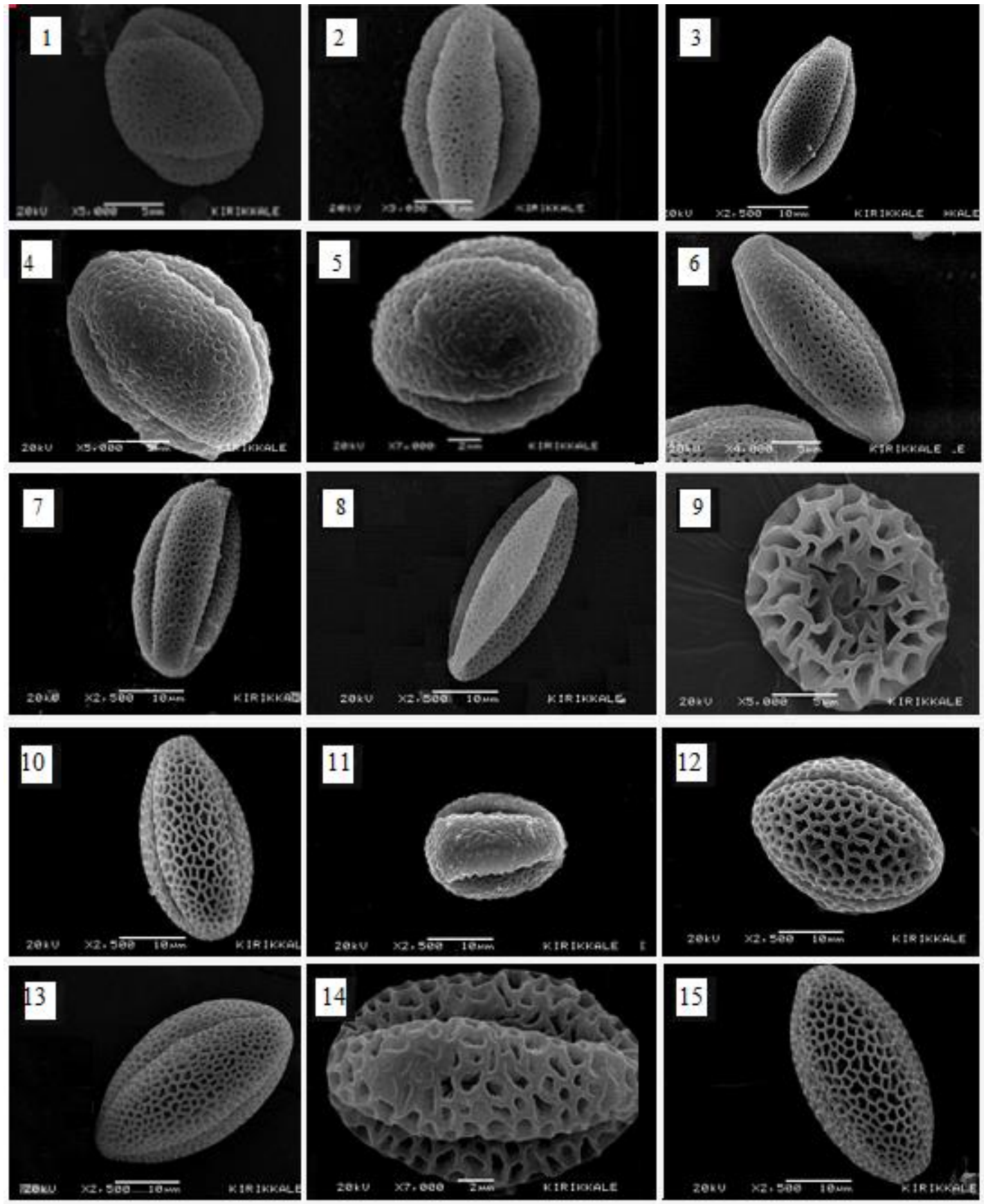

Figure 2. Scanning electron microscope photographs of the family Brassicaceae pollen grains: 1. Aethionema armenum; 2. Aethionema dumanii; 3. Alyssum turkestanicum; 4. Meniocus linifolius; 5. Odontarrhena muralis; 6. Odontarrhena sibirica; 7. Alyssum simplex; 8. Fibigia clypeata; 9. Matthiola longipetala; 10. Aubrieta libanotica; 11. Draba nana; 12. Brassica nigra; 13. Brassica elongata; 14. Crambe tataria; 15. Diplotaxis tenuifolia. 

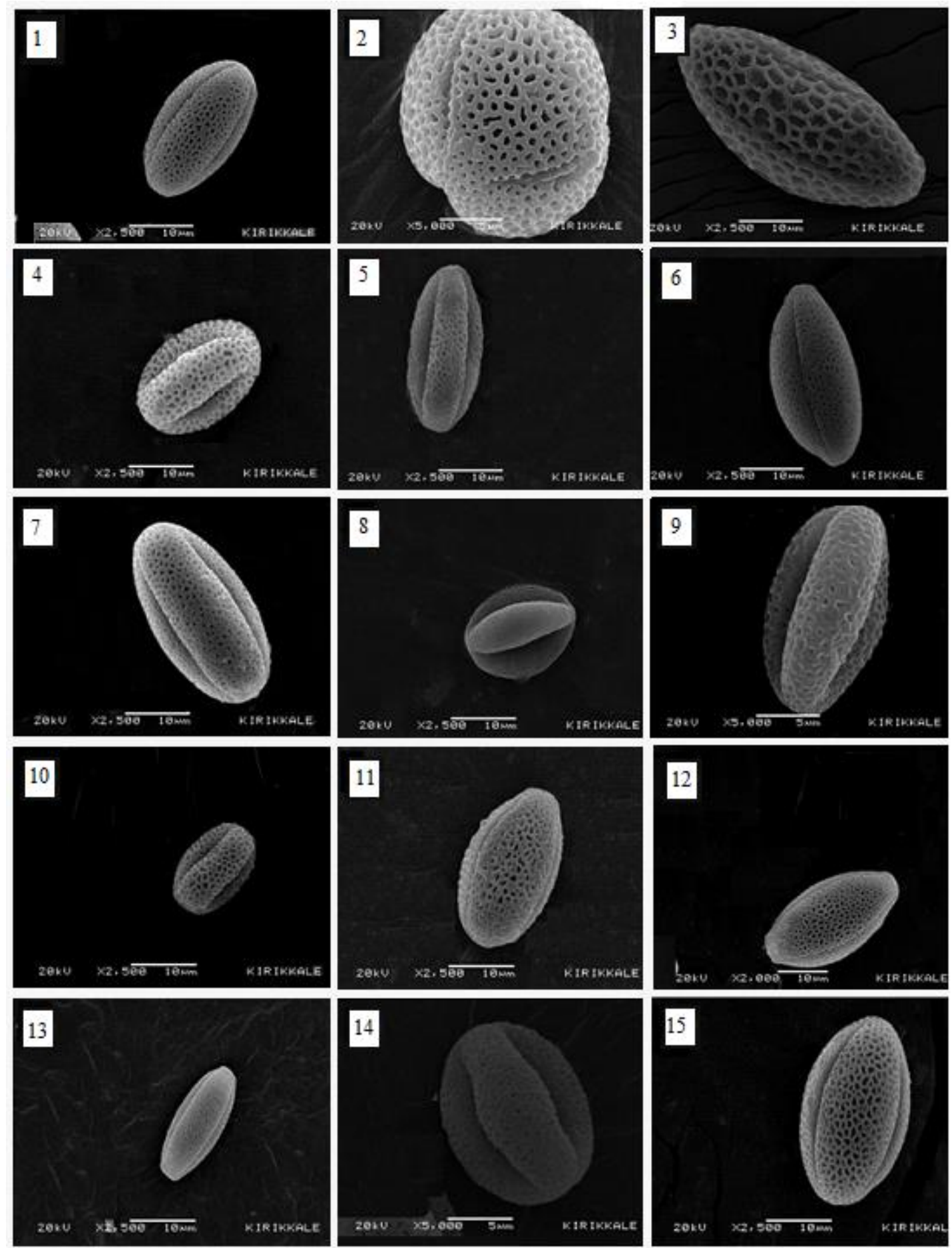

Figure 3. Scanning electron microscope photographs of the family Brassicaceae pollen grains: 1. Eruca vesicaria; 2. Hirschfeldia incana; 3. Sinapis arvensis; 4. Calepina irregularis; 5. Capsella bursa-pastoris; 6. Camelina hispida; 7. Camelina rumelica; 8. Neslia apiculata; 9. Barbarea vulgaris; 10. Chorispora tenella; 11. Microthlaspi perfoliatum, 12. Conringia orientalis; 13. Descurainia sophia; 14. Erysimum cuspidatum; 15. Erysimum repandum. 

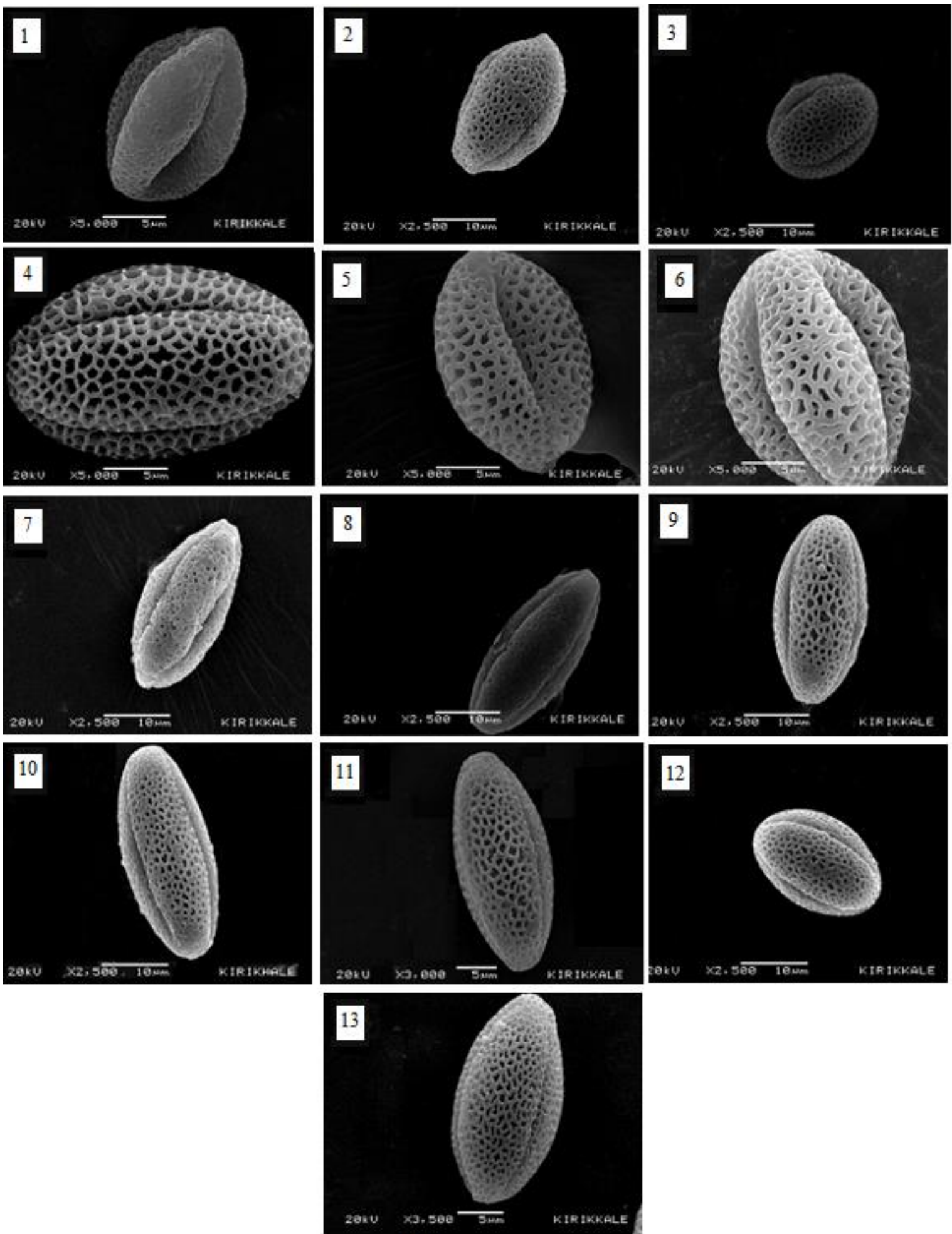

Figure 4. Scanning electron microscope photographs of the family Brassicaceae pollen grains: 1. Erysimum smyrnaeum; 2. Erysimum crassipes; 3. Strigosella africana; 4. Hesperis bicuspidata; 5. Isatis quadrialata, 6. Isatis glauca; 7. Lepidium draba; 8. Lepidium perfoliatum; 9. Sisymbrium altissimum; 10. Sisymbrium orientale; 11. Sisymbrium irio; 12. Sisymbrium loeselii; 13. Thlaspi arvense. 

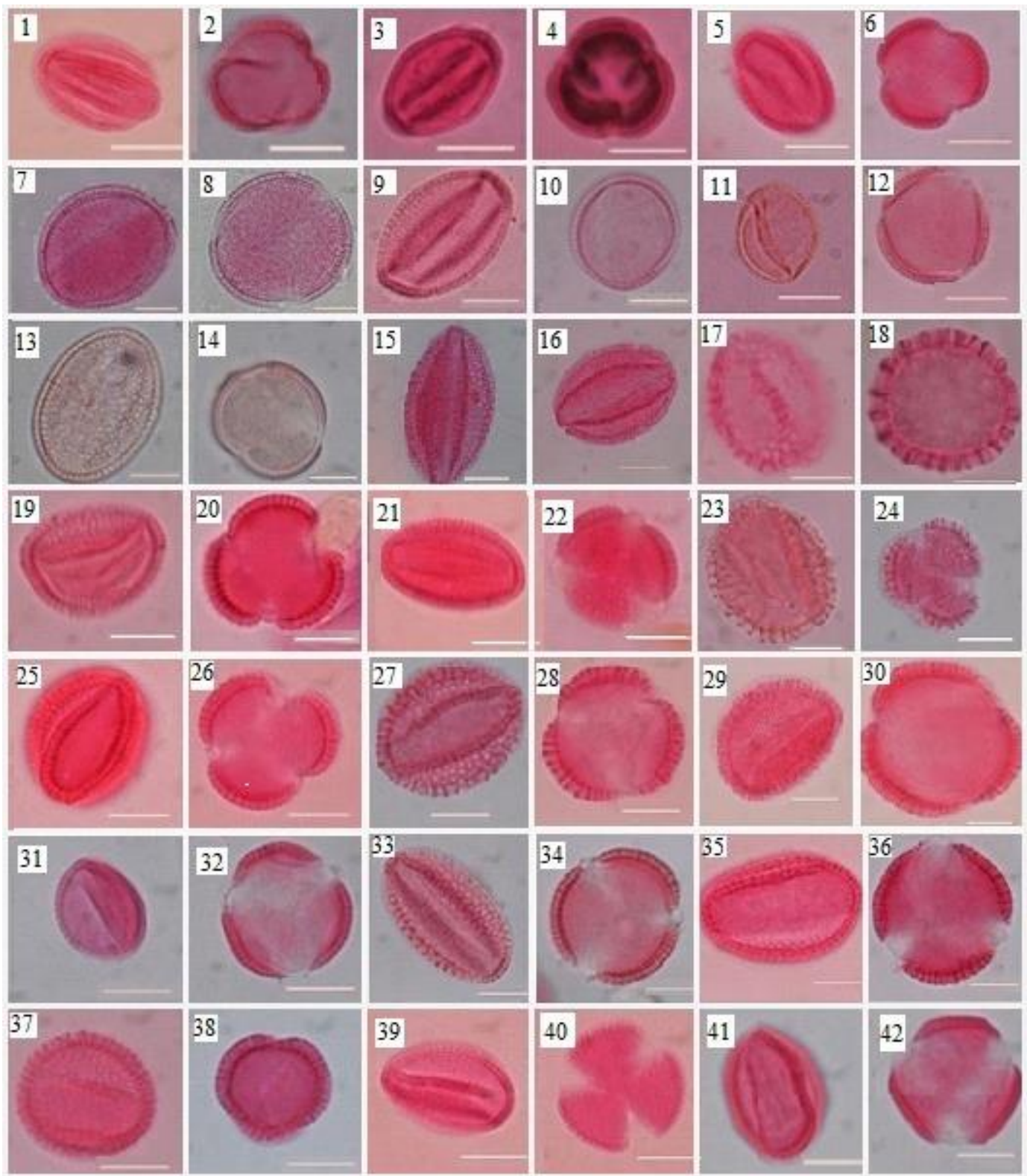

Figure 5. Light microscope photographs of the family Brassicaceae pollen grains: 1-2. Aethionema armenum; 3-4. Aethionema dumanii; 5-6. Meniocus linifolius;7-8. Alyssum turkestanicum; 9-10. Odontarrhena muralis; 11-12. Odontarrhena sibirica; 13-14. Alyssum simplex; 15-16. Fibigia clypeata; 17-18. Matthiola longipetala; 19-20. Aubrieta libanotica; 21-22. Draba nana; 23-24. Brassica nigra; 25-26. Brassica elongata; 27-28. Crambe tataria; $29-30$. Diplotaxis tenuifolia; 31-32. Eruca vesicaria; 33-34. Hirschfeldia incana; 35-36. Sinapis arvensis; 37-38. Calepina irregularis; 39-40. Capsella bursa-pastoris; 41-42. Camelina hispida. Scale bar: $10 \mu \mathrm{m}$. 

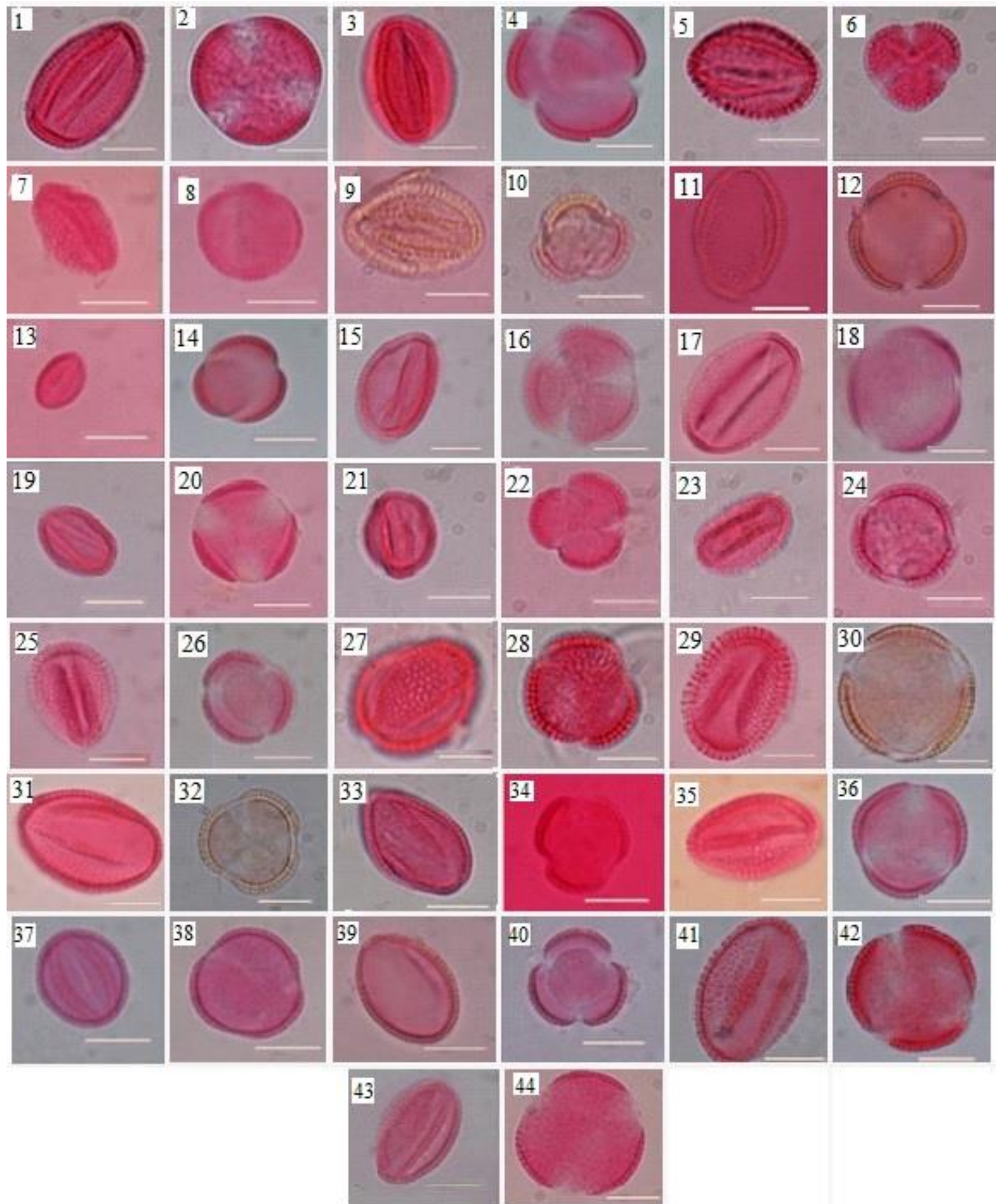

Figure 6. Light microscope photographs of the family Brassicaceae pollen grains: 1-2. Camelina rumelica; 3-4. Neslia apiculata; 56. Barbarea vulgaris; 7-8. Chorispora tenella; 9-10. Microthlaspi perfoliatum; 11-12. Conringia orientalis; 13-14. Descurainia sophia; 15-16. Erysimum cuspidatum; 17-18. Erysimum repandum; 19-20. Erysimum smyrnaeum; 21-22. Erysimum crassipes; $23-24$. Strigosella africana; 25-26. Hesperis bicuspidata; 27-28. Isatis quadrialata; 29-30. Isatis glauca; 31-32. Lepidium draba; 33-34. Lepidium perfoliatum; 35-36. Sisymbrium altissimum; 37-38. Sisymbrium orientale; 39-40. Sisymbrium irio; 41-42. Sisymbrium loeselii; 43-44. Thlaspi arvense. Scale bar: $10 \mu \mathrm{m}$.

\section{References}

[1] Yücel, E. \& Ezer, T. (2018). The bryophyte flora of Eskisehir Province (Turkey). Arctoa 27, 164-171. https://doi: 10.15298/arctoa.27.16

[1] Mummenhoff, K., \& Zunk, K. (1991). Should Thlaspi (Brassicaceae) be split? Preliminary evidence from isoelectric focusing analysis of Rubisco. Taxon, 40, 427-434.

[2] Mummenhoff, K., \& Koch, M. (1994). Chloroplast DNA restriction site variation and phylogenetic relationships in the genus Thlaspi sensu lato Brassicaceae. Systematic Botany, 19, 73-88. 
[3] Zunk, K., Mummenhoff, K., Koch, M., \& Hurka, H. (1996). Phylogenetic relationships of Thlaspi s.l. (subtribe Thlaspidinae, Lepidieae) and allied genera based on chloroplast DNA restriction-site variation. Theoretical and Applied Genetics, 92, 375381.

[4] Koch, M., \& Al-Shehbaz, I.A. (2004). Taxonomic and phylogenetic evaluation of the American Thlaspi Species: identity and relationship to the Eurasian genus Noccaea (Brassicaceae). Systematic Botany, 29, 375-384.

[5] Carlo, D, \& Paula, R. (2004). New insights into pollen evolution. International Journal of Plant Sciences, $164,835$.

[6] Davis, P.H., \& Heywood V.H. (1973). Principles of angiosperm taxonomy. Huntington, New York: Robert E. Kieger Publishing Co.

[7] Orcan, N., \& Binzet, R. (2004). A study of Alyssum floribundum (Brassicaceae). Phytologia Balcanica, 10 (2-3), $217-225$.

[8] Khalik, K.A., Van Den Berg, R.G., Van Der Maesen, L.J.G., \& El Hadidi, M.N. (2002). Pollen morphology of some tribes of Brassicaceae from Egypt and its systematic implications. Feddes Repertorium, 113, 211-223.

[9] Erdtman, G. (1972). Pollen morphology and plant taxonomy. New York.

[10] Sharma, R.R., \& Nair, P.K.K. (1973). A study on pollen production in Brassica L. Palynological Bull. V.J., 2, $62-66$.

[11] Carter, A.L., Williams, S.T., \& McNeilly, T. (1975). Scanning electron microscope studies of pollen behaviour on immature mature Brussels sprout (Brassica oleracea var. gemmifera) stigmas. Euphytica, 24, 133-141.

[12] Appel, O. and Al-Shehbaz, I.A. (2002). Cruciferae. In: The Families and Genera of Vascular Plants. Flowering Plant Dicotyledons, Malvales, Capparales and Non-Betalain Caryophyllaceae. Kubitzki, K and C. Bayer (Eds.) vol.5, 75-174. New York: Springer-Verlarg, Berlin Heidelberg,

[13] Mutlu, B., \& Erik, S. (2012). Pollen morphology and its taxonomic significance of the genus Arabis (Brassicaceae) in Turkey. Plant Systematics and Evolution, 298, 1931-1946.

[14] Erdtman, G. (1952). Pollen morphology and plant taxonomy. Angiosperms. Stockholm: Almquist and Wiksell.

[15] Khan, R. (2004). Studies on the pollen morphology of the Genus Arabidopsis (Brassicaceae) from Pakistan. Pakistan Journal of Botany, 36(2), 229-234.

[16] Perveen, A., Qaiser, M., \& Khan, R. (2004). Pollen flora of Pakistan-XLVII. Brassicaceae. Pakistan Journal of Botany, 36, 683-700.

[17] Sagun, V., \& Auer, C. (2016). Pollen morphology of selected species in the Camelineae (Brassicaceae). Palynology, 41(2), 255-266.

[18] Ančev, M., \& Deneva, B. (1997). Pollen morphology of seventeen species from family Brassicaceae (Cruciferae). Phytologia Balcanica, 3, 75-82.

[19] Doğan, C., \& İnceoğlu, O. (1990). Pollen morphology of some Isatis L. taxa in Turkey. Turkish Journal of Botany, 14, $12-31$.

[20] Brochmann, C. (1992). Pollen and seed anatomy of Nordic Draba (Brassicaceae phytogenetic and ecological implications. Nordic Journal of Botany, 12(6), 657-673.

[21] Pınar, N.M., Duran, A., Çeter, T., \& Tuğ, G.N. (2009). Pollen and seed morphology of the genus Hesperis L. (Brassicaceae) in Turkey. Turkish Journal of Botany, 33, 83-96.

[22] Kızılpınar, İ., Altınözlü, H., \& Doğan, C. (2012). Pollen morphology of the some species of the genus Malcolmia (Brassicaceae). Mellifera, 12(23), 24-29.

[23] Karaismailoğlu, M.C. (2017). Palynological features of eleven Aethionema taxa from Turkey and their systematic implications. Bangladesh Journal of Plant Taxonomy, 24(2), 197-204.

[24] Erdtman, G. (1954). An introduction to pollen analysis. Stockholm: Almqvist and Wiksell.

[25] Erdtman, G. (1960). The acetolysis method. A revised description. Svensk Botanisk Tidskrift. 54, 561-564.

[26] Menemen, Y., \& Jury, S. L. (2001). A taxonomic revision of the genus Pastinaca L., (Umbelliferae). Israel Journal of Plant Sciences, 49: 67-77.

[27] Punt, W., Hoen, PP., Blackmore, S., Nilssony, S., \& Le Thomas, A. (2007). Glossary of pollen and spore terminology. Review of Palaeobotany and Palynology, 143, 1-81.

[28] Erdtman, G. (1943). An introduction to pollen analysis. Waltham, Mass: Chronica Botanica Company.

[29] Lahham, J. N., \& Al-Eisawi, D. (1987). Pollen morphology of Jordanian Cruciferae. Mitteilungen der Botanischen Staatssammlung München. 23, 355-375.

[30] Atçeken, M.M., Dural, H., \& Çıtak, B.Y. (2016). The morphological, anatomical and palynological investigations on some taxa of genus Aethionema A.T. Waiton (Brassicaceae). Biodicon, 9(1), 55-68.

[31] Jonsell, B. (1979). New taxa of Cruciferae from East tropical Africa and Madagascar. Botanisca Notiser, 132, 521-544.

[32] İnceoğlu, Ö., \& Karamustafa, F. (1975). The pollen morphology of plants in Ankara region II. Cruciferae. Commommunication Faculty of Sciences University of Ankara Series, C2, 21, 111-118.

[33] Kiefer, M., Schmickl, R., German, D.A., Mandáková, T., Lysak, M.A., Al-Shehbaz,... Koch, M.A. (2014). BrassiBase: Introduction to a novel knowledge database on Brassicaceae evolution. Plant Cell Physiology, 55(1), 1-9.

[34] Çıtak, B.Y., Dural, H., \& Gönen., B. (2016). Selçuk Üniversitesi Alâeddin Keykubat Kampüsü’nde Yayılış Gösteren Bazı Bitkilerin Polen Morfolojileri. Fen Fakültesi Fen Dergisi, 42 (1), 42-56.

[35] Çetin, Ö., Duran, A., Martin, E., \& Tuştaş, S. (2012). A taxonomic study of the genus Fibigia Medik. (Brassicaceae). African Journal of Biotechnology, 11(1), 109-119. 